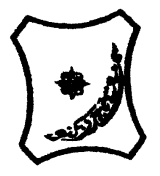

Bayero Journal of Pure and Applied Sciences, 10(1):192 - 197

ISSN 2006 - 6996

\title{
SOME ASPECTS OF FISHERIES ECOLOGY IN THOMAS DAM, KANO NIGERIA
}

\author{
${ }^{1 * N a f i u, ~ S . ~ A ., ~}{ }^{1}$ Badamasi, I., ${ }^{2}$ Ahmad, M. K., ${ }^{1}$ Abdullahi, M. T., ${ }^{3}$ Yelwa, S. I. and ${ }^{1}$ Ibrahim, \\ B.A. \\ ${ }^{1}$ Department of Science Laboratory Technology, Kano State Polytechnic, Kano \\ ${ }^{2}$ Department of Biological Sciences, Bayero University Kano \\ ${ }^{3}$ College of Art, Science and Remedial Studies, Tudunwada, Kano State \\ *Correspondence author: nafiune.sn@gmail.com, +23407030918094
}

\section{ABSTRACT}

The diversity, length-weight relationship and condition factor of fish species of Thomas Dam, Dambatta Kano were studied fortnightly between November, 2016 and February, 2017. Fish species were collected using line nets, cast nets, hooks and traps; weighted to the nearest gram and standard length measured to the nearest centimeter. A total 313 fishes comprising of 7 families and 11 species were identified. Family cichlidae was predominant(36.7\%) represented by T. zilli (21.7\%) and Oreochromis niloticus (15.0\%). Family Claridae was the second highest in abundance with $24.7 \%$ represented by $C$. garipienus (8.9\%), Clarias anguillaris (8.9\%) and Heterobranchus sp. (6.7) while Protopteridae represented by Protopterus sp. was the least with 2.8\%. Species diversity determined by Shannon Weiner index of diversity, Evenness index and Margalef's index which revealed the highest value at site $A$ of $1.45,0.78$ and 2.66 while site $D$ had the least with $1.1,0.64$ and 1.72 respectively. Growth coefficient $b$ of the length weight relationship ranged from 0.9 to 2.7 inHeterobranchussp. andClariasgariepinus. The $b$ values of the all the fish species is less than the mean exponent $b=3$, indicating a negative allometric growth. Condition factor $(K)$ for all fish species differed significantly $(P<0.05)$ as the highest value was recorded in Mormyrus rume and Heterobranchus sp. with 1.9 each and the least were C. gariepinus and C. anguillaris, protopterus sp. and Labeo senegalensis each had 0.9 values respectively. The mean condition factor $(K)$ by species was greater than 1 , indicating that the fish species were not in good condition.

KEY WORDS: Species diversity, Length-weight relationship, Condition factor, Allometric growth, Thomas Dam, Dambatta Kano State.

\section{INTRODUCTION}

Reservoirs are created usually for a particular purpose either to generate electricity, irrigation or domestic usage. Irrespective of the main objective, the fish yield from such Reservoirs constitute a substantial contribution to a country's total domestic fish production (Dankishiya et al., 2012). For sustainability of these resources, an adequate knowledge of species composition, diversity and relative abundance of the water bodies must be understood and vigorously pursued (Lawson and Olusanya, 2010). Balogun (2005) stated that length- weight relationships provide valuable information on the habitat where the fish lives. It provide important clues on climatic and environmental changes in an aquatic ecosystems. Moreover, condition factor is also a useful index for monitoring feeding intensity, age and growth rates in fish
(Ndimele et al., 2010). In view of the foregoing this study aimed at assessing the fish species composition, length-weight relationship and condition factor of Thomas Dam Dambatta, Kano Nigeria.

\section{MATERIALS AND METHODS}

Study Area

Thomas Dam is located within Sudan savannah zone of Nigeria $\left(12^{\circ} 1644^{\prime \prime} \mathrm{N}-21^{\circ} 18^{\prime} 35 \mathrm{~N}\right.$ and $\left(8^{\circ} 30^{\prime} 5^{\prime \prime} \mathrm{E}-8^{\circ} 31^{\prime} 34^{\prime \prime} \mathrm{E}\right)$ with two distinct wet and dry seasons. The rainy season lasts from May to October and dry season runs from November to April (Shitu, 2006). The Dam is about 585 square meters, while its depth is about $30 \mathrm{~m}$. The dam is sited near Danmarke village of Dambatta Local Government area of Kano State, $30 \mathrm{~km}$ away from the ancient Kano City (Kutama et al., 2013). 


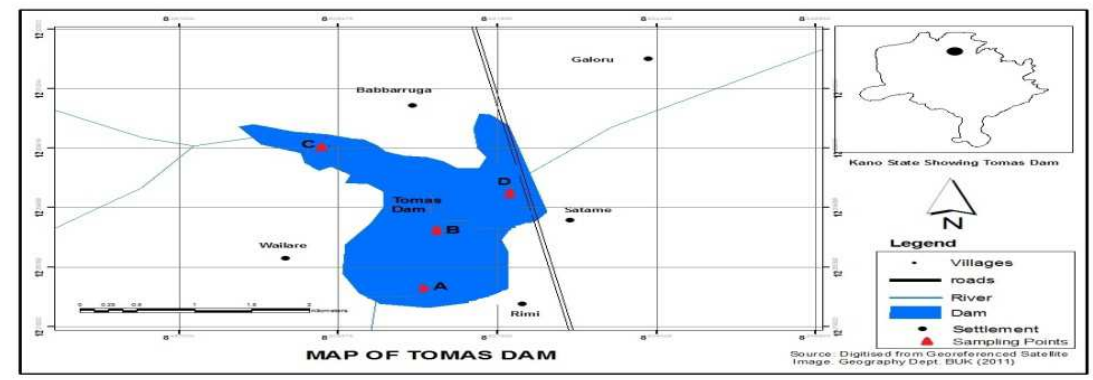

Figure 1: Thomas Dam, Kano State with Marked Sampling Sites Source: Google Earth (2016).

\section{Sampling Sites}

Four (4) sampling sites were chosen for the purpose of this study and designated as A, B, C, and $D$ on the water course of the dam. The choice of the sites was based on the morphomerty of the sampling area.

Collection and Identification of Fish species

Fish samples were collected fortnightly for a period of four months (November, 2016 to February, 2017) from each sampling sites A, B, C and $D$ using a fishing gear such as gill nets, cast nets, traps and hook with help of fisher men as described by Badamasi (2014). Fish captured were stored in ice block and immediately transported to the laboratory for further analysis. They were counted, weighted to the nearest $0.1 \mathrm{~g}$ using weighing balance (TF220 Model). The standard lengths and total lengths measured to the nearest $0.1 \mathrm{~cm}$ on a measuring board. The biometric features such as the type of mouth, position of the mouth, fin count, spine count, barbell counts and position, kind of teeth, dorsal and anal fin rays count, gill raker count, body shape, size, colour and shape of the caudal fin were examined on the fish species using identification key by Olaosebikan and Raji (1998). The length-weight relationship was calculated using the least square regression on log transformation of the equation. The length weight relationship was expressed by the equation:

$\log W=\log a+b \log L$ where $W=$ Weight, $T L=$ Total Length, $a=$ exponent describing of the rate of change of weight with length (intercept), b = weight at unit length. Fulton's condition factor as described by Begenal (1978) was used from the expression $K=100 \mathrm{~W} / \mathrm{L}^{3}$.

$\mathrm{K}=$ condition factor, $\mathrm{W}=$ total weight $(\mathrm{g}), \mathrm{L}$ $=$ total length $(\mathrm{cm})$ and $3=$ the cubic relationship between length and weight
Determination of Biotic Indices

Shannon-Weaner (1949) diversity index (H), species evenness and Margalef's diversity index were used to determine the fish species diversity. The Shannon - Weiner equation is as follows:

Shannon Index $(\mathrm{H})=-\Sigma 1 \ln \mathrm{pi} \ln \mathrm{pi}$

Where $\mathrm{pi}=$ the proportion of the $\mathrm{i}^{\text {th }}$ species in the No. of individual species

sample (total number of samples $)$

$\mathrm{H}=$ the Shannon - wiener ' index of diversity

$\mathrm{S}=$ number of species or species richness

$\mathrm{H}_{\max }=$ Maximum diversity possible

$\mathrm{E}=$ Eveness $={ }^{H} / H_{\text {max }}$

Margalef's index (d) measures species richness and diversity in the community structure. The equation described by Margalef (1967) was applied in the calculation. $\mathrm{d}=\frac{5-1}{\operatorname{In}(N)} \quad$ Where: $\mathrm{d}=$ species richness index
$\mathrm{S}=$ Number of species population $\mathrm{N}=$ Total number of individual species.

\section{Statistical Analyses}

On way Analysis of variance (ANOVA) was used to compare the means between sites and months of fish species to find out if there is significant difference or otherwise. Duncan Multiple Range Test was used to separate the means. Student's $t$ test was used to determine the exponents (b) of the length and weight relationship.

\section{RESULTS}

A total of 313 individuals representing 7 families and 11 species were identified between November, 2016 and February, 2017 in which family cichlidae was the most abundant consisting of $36.7 \%$ represented by $T$. zilli(21.7\%) and Oreochromisniloticus (15.0\%). Family Claridae was the second highest in abundance with $24.5 \%$ represented by C. garipinus (8.9\%), Clarias angullaris (8.9\%) and Heterobranchus sp. (6.7\%). Protopteridae represented by Protopterus sp. was the least family recovered with $2.8 \%$ (Table 1). 
Special Conference Edition, November, 2017

Table 1: Monthly Composition of Fish Species Caught in Thomas Dambatta Kano (November, 2016 Feburary, 2017)

\begin{tabular}{|c|c|c|c|c|c|c|c|c|}
\hline Family & Species / Month & November & December & January & February & Total & $\begin{array}{l}\% \\
\text { Species }\end{array}$ & Family \\
\hline Alastidae & Brycinus nurse & 11 & 6 & 6 & 4 & 27 & 8.6 & 8.6 \\
\hline \multirow[t]{2}{*}{ Mormydae } & Mormyrus rume & 2 & 5 & 4 & 3 & 14 & 4.6 & \\
\hline & $\begin{array}{l}\text { Mormyrus } \\
\text { anguillodes }\end{array}$ & 7 & 8 & 2 & 7 & 24 & 7.6 & 12.2 \\
\hline \multirow[t]{3}{*}{ Claridae } & Clarias gariepinus & 11 & 7 & 6 & 4 & 28 & 8.9 & \\
\hline & Clarias angullaris & 12 & 7 & 3 & 6 & 28 & 8.9 & \\
\hline & Heterobranchus sp. & 11 & 4 & 4 & 2 & 21 & 6.7 & 24.7 \\
\hline \multirow[t]{2}{*}{ Cichlidae } & Tilapia zilli & 18 & 14 & 14 & 22 & 68 & 21.9 & \\
\hline & Orechromis niloticus & 22 & 13 & 7 & 5 & 47 & 15 & 36.7 \\
\hline Protopteridae & Protopterus sp. & 3 & 1 & 4 & 1 & 9 & 2.8 & 2.8 \\
\hline Centropomidae & Lates niloticus & 13 & 12 & 6 & 4 & 35 & 11.2 & 11.2 \\
\hline \multirow[t]{3}{*}{ Cyprinidae } & Labeo senegalensis & 5 & 2 & 2 & 3 & 12 & 3.8 & 3.8 \\
\hline & $\begin{array}{l}\text { Total no. of } \\
\text { individuals }\end{array}$ & 115 & 79 & 58 & 61 & 313 & 100 & 100 \\
\hline & $\%$ composition & 37.1 & 25.9 & 17.8 & 19.2 & 100 & & \\
\hline
\end{tabular}

Table 2 illustrates species diversity based on the sites in which site A had the highest Shannon- Weiner index , Evenness index and Margalef's index of $1.45,0.78$ and 2.66 while site $D$ had the least with 1.1, 0.64 and 1.72 respectively. The Shannon-wiener index $\left(\mathrm{H}^{\prime}\right)$ for all the fish species encountered were within the range of 1.1 to 1.45 .

Table 2: Species diversity of Fish from Thomas Dam, Dambatta Kano at the various Sampling Sites (November, 2016 -February, 2017)

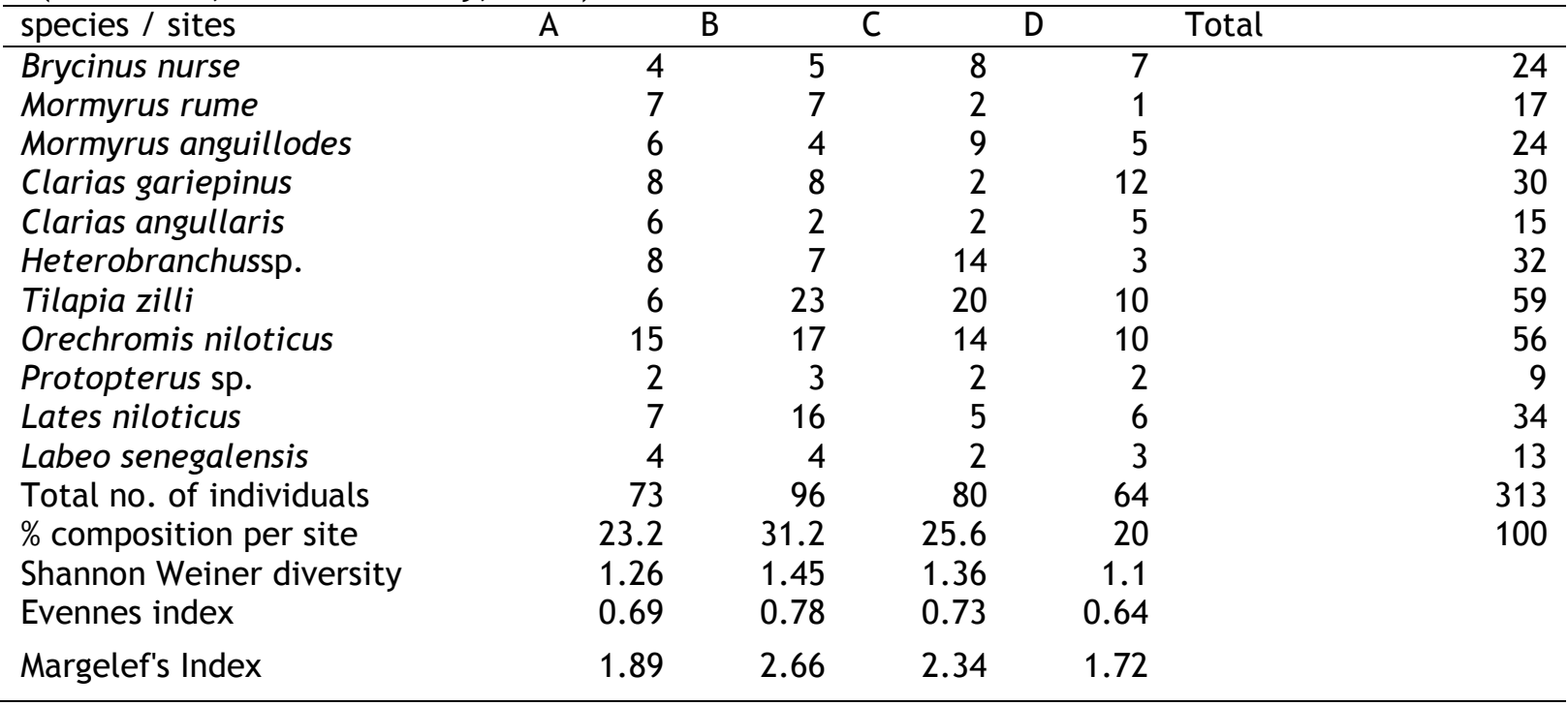

The length -weight relationship, condition factor (K) and growth pattern relationship coefficient between length and weight with regression equation were presented in Table 3 . In the present study ' $b$ ' value of all species differ significantly $(P<0.05)$ with the highest recorded in Heterobranchus sp. (2.7) and the lowest in Clarias gariepinus (0.9) The mean value of $b$ for all species was 1.92 which exhibited negative allometric growth.
The condition factors $(K)$ for all species differed significantly $(p<0.05)$ as the highest value was recorded in Mormyrus rume and Heterobranchus sp. with 1.9 each followed by Oreochromis niloticus (1.8) and the least were $C$. garipinus and $C$. anguillaris, protopterus sp. and Labeo senegalensis each had 0.9 values respectively ( Table 3). 
Special Conference Edition, November, 2017

Table 3: Length- Weight Relationship and Condition Factor of Fish Species Identified In Thomas Dam,Dambatta(November, 2016 -February, 2017)

\begin{tabular}{|c|c|c|c|c|c|c|c|c|}
\hline Species & $\begin{array}{l}\text { MTL } \\
(\mathrm{cm})\end{array}$ & $\begin{array}{l}\text { mean } \\
\text { weigh } \\
t(g)\end{array}$ & $\begin{array}{l}W-L \text { equation } \\
W=a L^{b}\end{array}$ & $\begin{array}{l}\text { Determin } \\
\text { ation } \\
\text { Coefficie } \\
\text { nt }\left(r^{2}\right)\end{array}$ & Corre $r$ & $\begin{array}{l}\text { Con. } F \\
\text { (K) }\end{array}$ & 'b' & GT \\
\hline Brycinus nurse & 22 & 160 & LogW=log $123+1.5 \log 65$ & 0.107 & 0.327 & 1.5 & 1.7 & NA \\
\hline Mormyrus rume & 24.2 & 274 & $\log W=\log 242+1.5 \log 70$ & 0.107 & 0.327 & 1.9 & 1.7 & \\
\hline $\begin{array}{l}\text { Mormyrus } \\
\text { anguillodes }\end{array}$ & 29 & 261 & $\log W=\log 236+1.0 \log 84$ & 0.058 & 0.24 & 1 & 1.1 & \\
\hline Clarias gariepinus & 32 & 302 & $\log W=\log 320-0.5 \log 99$ & 0.036 & 0.189 & 0.9 & 0.9 & \\
\hline Clarias angullaris & 31 & 280 & $\log W=\log 266+0.6 \log 94$ & 0.062 & 0.249 & 0.9 & 1.6 & \\
\hline $\begin{array}{l}\text { Heterobranchus } \\
\text { sp. }\end{array}$ & 23 & 243 & $\log W=\log 128+5.5 \log 66$ & 0.99 & 0.99 & 1.9 & 2.7 & \\
\hline Tilapia zilli & 23 & 164 & $\log W=\log 146+0.8 \log 77$ & 0.851 & 0.923 & 1.3 & 2.4 & \\
\hline $\begin{array}{l}\text { Orechromis } \\
\text { niloticus }\end{array}$ & 21 & 173 & LogW=log138+1.8log56 & 0.942 & 0.971 & 1.8 & 2.3 & \\
\hline Protopterus sp. & 29 & 216 & $\log W=\log 188+1.0 \log 78$ & 0.519 & 0.721 & 0.9 & 2 & \\
\hline Lates niloticus & 24 & 237 & $\log W=\log 201+1.5 \log 69$ & 0.964 & 0.982 & 1.7 & 2.5 & \\
\hline $\begin{array}{l}\text { Labeo } \\
\text { senegalensis }\end{array}$ & 16 & 37 & $\log W=\log 59.5-1.5 \log 51$ & 0.75 & 0.866 & 0.9 & 2.2 & \\
\hline
\end{tabular}

Key: Corre $=$ correlation coefficient, Con. $\mathrm{F}=$ condition factor, $M T L=$ mean total length, $\mathrm{GT}=$ Growth type, NA= ve allometric

\section{DISCUSSION}

A total of 313 fish species representing 7 families and 11 species were identified in the present study which revealed a relatively higher species diversity when compared with three families and five species recorded by Abdullahi and Mukhtar (2015) in the same water body. The variation in the number of families recorded might be due to the increased availability of food (plankton), low predation and good spawning ground in the dam which enhanced their breeding potentials. Similar observation was reported by Mustapha (2009) and Dankishiya et al. (2012). The present finding also conforms with the works of other authors within the same ecological zone such as Lamai and Kolo (2003) who identified 4 fish families consisting of five (5) species in Dan-Zaria dam, Balaet al. (2009) Seven (7) families comprising eleven (11) species in Daberam, Daura Katsina State, Nazifi and Abubakar (2013) eleven families 16 species in DadinKowa Dam, Gombe State, Ataguba et al. (2014) six families belonging to 18 species in Gubi Dam Bauchi State and Abdullahi and Mukhtar (2015) five families consisting of six species in Daberam Dam, Daura Kastina State. In the present study Tilapia zilli (family Cichlidae) was the most abundant with (36.7\%) in the dam while
Protopterus sp. had the least with (2.8\%). Their high abundance could be attributed to the high prolific breeding nature of members of the family Cichlidae as reported by Ita et al. (1993), Dankishiya and Abdulrahman (2007) in Geriyo Dam Adamawa State. The seven (7) families were common throughout the study period which perhaps could be due to the relative abundance of these species in northern Nigeria as reported by Ita (1993) and Adeosun et al. (2011). Percentage composition of fish species according to sites revealed that site $B$ had that highest with $31.2 \%$ followed by site $C$ with $25.6 \%$ and the least was site D with $20.0 \%$.

Species diversity based on the site revealed that site $A$ had the highest while site $D$ recorded the least. The low species diversity at site $D$ could be due to the likelihood of unbalanced ecological community between forage and carnivores species ratio at the site and possibly over exploitation of the family members by fishers as reported by Ita (1993) and Oguntade et al. (2014).Based Shannon-wiener index ( $\left.H^{\prime}\right)$ the values obtained during this study of 1.1 to 1.45 indicates low species diversity. Similar observation was reported by Mwangi et al. (2012). 
This perhaps is attributed to the morphology and hydrology of the dam which increase its habitat homogeneity resulting in smaller habitat niches as reported (Mwangi et al., 2012). Species evenness index across the sites revealed that the distribution of fish population is even since the values are close to 1 . The values are within the range reported by Ataguba et al. (2014) in Gubi Dam Bauchi State.

The " $b$ " values in length-weight relationship determine the growth pattern of the fish species (Datta et al., 2013). Wootton (1990) described growth as positive allometric when weight of an organism increases more than length $(b>3)$ and negative allometric when length increases more than weight $(b<3)$. In the present study ' $b$ ' value of all species differ significantly $(p<0.05)$ with the highest recorded in Heterobranchus sp. (2.7) and the lowest in Clarias gariepinus (0.9) The mean value of $b$ for all species was 1.92 which exhibited negative allometric growth indicating that they become thinner with increase in length (negative allometric) as reported by Datta et al. (2013). The b values recorded for $C$. gariepinus $(0.9)$ is lower than the $b$ values obtained from studies of Bala et al. (2009) and Imam et al. (2010) of 2.79 and 2.81 for $C$. gariepinus and C. gariepinus respectively. This indicated that the rate of increase in body length is not proportional to the rate of increase in body weight, in the present finding indicating negative allometric growth when compared with the mean exponent $b=3$. The values negates what was observed by Oniye et al. (2006) who obtained the b-value for $P$. annectens in Jachi Dam between 3.12 and 3.22. The variation of length- weight relationship recorded in this study could be due to the condition of the fish caught, season and nature of the water body as reported by Oniye et al. (2006). In fisheries science, the condition factor is used in order to compare the condition,

\section{REFERENCES}

Abdullahi, U. A. and Mukhtar, U. Y. (2015). Appraisal of The Current Fish Composition, Abundance and Operative Fishing Gears in Tomas Dam Dambatta, Kano State and Daberam Dam Daura, Katsina State. Bayero Journal of Pure and Applied Sciences, 8(1): 6 $-9$.

Adeosun, F. I., Omoniyi, Y., Akegbejo-Samson, Y and Olujimi, O. O. (2011). The fishes of Ikere Gorge drainage system in Ikere, Oyo State, Nigeria. Asiatic Journal of Biotechnology Resources, 2(4): 374-383. fatness or wellbeing of fish (Oniye et al., (2006). The condition factors $(K)$ for all species differed significantly $(p<0.05)$ as the highest value was recorded in Mormyrus rume and Heterobranchus sp. with 1.9 each followed by Oreochromis niloticus (1.8) and the least were $C$. garipinus and C. anguillaris, Protopterus sp. and Labeo senegalensis each had 0.9 values respectively. The variation in the species condition factor could be related to the wellbeing and degrees of fatness (Mustapha, 2009). In the present study the condition factors $(K)$ of the eleven species ranged between 0.9 and 1.9 and the mean condition factor $(K)$ by species was 1.3 , greater than 1 indicating that all the fish species were in good condition which is in tandem to what was obtained in other fresh water bodies within the same ecological zone, for instance a range of between 0.49 - 1.48 was recorded by Bala et al. (2009) recorded mean $K$ value of 1.140 in Daberam Reservoir Kastina State, Imam et al. (2010) recorded K-value between 2.44 to 2.77 in Wasai Resevoir Kano, Ibrahim et al. (2012) recorded a mean K-value of $1.98 \pm 0.35$ in Kontagora Reservoir in Niger State and Nazifi and Abubakar (2013) recorded K- value between 0.7 to 1.8 in Dadin Kowa Dam Gombe State.

\section{CONCLUSION AND RECOMMENDATIONS}

The present finding indicates lower fish diversity in the study area compared to the results of other studies in the same ecozone. The lengthweight relationship revealed general negative allometric growth. The values for condition factor indicate that the fish were not in good condition during the study period. Improper management of the fishery resources in the Dam need to be addressed by the relevant authorities and NGOs using of integrated programs with the view of conserving and sustaining the fishery resources of Thomas Dam for future exploitation.

Ataguba, G. A; Tachia, M. U and Aminu, G. (2014). Fish Species Diversity and Abundance of Gubi Dam, Bauchi State of Nigeria. Asian Journal of Conservation Biology, 3(1): 60-67.

Badamasi, I. (2014). Distribution of Stomach Food Content of Fish Species Collected from Industrial Waste Water Effluents. A Case Study of Jakara Dam.International Journal of Innovation and Technology, 5(2):124-129.

Bala, U; Lawal,I; Bolorunduro,P.I; Oniye,S.J; Abdullahi, S.A; and Bichi, A. H.(2009). Study of ichtyofauna of Daberam. Reservoir in 
Katsina state. Bayero Journal of Pure and Applied Sciences, 2(2):172-174.

Balogun, J. K. (2005). Fish Distribution in a Small Domestic Water Supply Reservoir: A Case Study of Kangimi Reservoir, Kaduna, Nigeria. Journal of Applied Science of Environmental Management, 9(1): 93-97.

Begenal, T. B. (1978): Aspect of fish fecundity. In: S. D. Gerking (Ed) Ecology of Freshwater fish production. Blackwell scientific publications, Oxford: 75-101.

Datta, S. N, Vaneet, I. K; Asha, D and Geeta, J.(2013). Estimation of length-weight relationship and condition factor of spotted snakehead Channapunctata (Bloch) under different feeding regimes. Springer Plus, 2: 436.

Dankishiya, A. S. and Abdulrahaman, K. A. (2007). Check list of fish fauna in Lake Geriyo, Yola, Adamawa State. Biological and Environmental Science Journal for the Tropics, 4 (2): 75-78.

Dan-kishiya, A. S., Olatunde, A. A and Balogun, J. K. (2012). Fish Species Distribution in a Domestic Water Supply Reservoir: A Case Study of Lower Usuma Reservoir, Bwari, Nigeria. Researcher, 4(2):56-60.

Ibrahim, B. U., Auta, J. and Balogun, J. K (2012). Survey of Fish Biodiversity of Kontagora Dam, Niger State, Nigeria. Nigerian Journal of Fisheries Science and Technology, 1: 47-54.

Imam, T. S, Bala, U., Balarabe, M. L and Oyeyi, T. I. (2010). Length-weight relationship and condition factor of four fish species from Wasai Reservoir in Kano, Nigeria. African Journal of General Agriculture, 6 (3): 125130.

Ita, E. O. (1993). Inland Fishery Resources of Nigeria. Central Insitute of Freshwater Aquaculture Occassional Paper, 20: 120-126.

Kutama, A.S., Umar, S., Fagwalawa, L.D, Ahmed, M.K and Bilkisu, A.I. (2013). Detection of Fish Saprolegniasis in Thomas Dam and Challawa Commercial Fish Pond:Global Advanced Research Journal of Agricultural Science, 2(12):315-321.

Lawson, O. E and Olusanya O. M. (2010). Fish Diversity in Three Tributaries of River Ore, South West, Nigeria. World Journal of Fish and Marine Sciences 2 (6): 524-531.

Lamai, S. L and Kolo, R. J. (2003). Biodiversity and abundance of fish and plankton of DanZaria Dam, Niger State, Nigeria. Journal of Aquatic Science, 18(2): 141 - 148.
Margalef, R. (1967). Diversity and Stability: A practical Proposal and a Model of Interdependence. Brookhaven Symposium on Biology; 22(1): 25-37.

Mustapha, M. K. (2009). Fish Fauna of Oyun Reservoir, Offa, Nigeria. Journal of Aquatic Sciences. The Association of Aquatic Sciences of Nigeria, University of Jos. Nigeria. Available online at http://www.ajol.info/index.php/jas.

Mwangi, B. M., Ombogo, M. A., Amadi, J., Baker, $\mathrm{N}$ and Mugalu, D. (2012). Fish Species Composition and Diversity of Small Riverine Ecosystems in the Lake Victoria Basin, Kenya. International Journal of Science and Technology. 2(9): 675- 680

Nazeef, S and Abubakar, U. M. (2013). Diversity and Condition Factor of Fish Species of DadinKowa Dam, Gombe State, Nigeria. Greener Journal of Biological Sciences, 3(10): 350- 356.

Ndimele, P. E., Kumolu-Johnson, C. A., Aladetohun, N. F and Ayorinde, O. A. (2010). Length-weight relationship, condition factor and dietary composition of Sarotherodonmelanotheron, Ruppell, 1852 (Pisces: Cichlidae) in Ologe Lagoon, Lagos, Nigeria. Agricultural and Biological Journal North America, 1: 584-590.

Oguntade, O. R., Oketoki, O. T., Ukenye, E. A., Usman, B. A. and Adeleke, M. T. (2014). Survey of the Present and Fast Disappearing Fish Species along Two Rivers in Niger Delta, Nigeria. Journal of Fisheries and Aquatic science, 9(5): 352-358.

Oniye, J. S., Adebote, D. E., Usman, S. K. and Makpo, J. K. (2006). Some aspect of the biology of Protopterusannectens in Jachi Dam near Katsina, Katsina State Nigeria. Journal of Fisheries and Aquatic Science, 1(2):136 141.

Olaosebikan, B. D and Raji, A. (1998). Field Guide to Nigeria Freshwater Fishes. Federal College of Freshwater Fisheries Technology Publication. Decency printers, Ilorin, Nigeria. 110pp.

Shannon, C. E, and Weaver, W. (1949). The Mathematical Theory of Communication. Urban University, Illinois Press, Illinois, P. 125.

Shitu M.B. (2006). State Educational Sector Project: Institutional Assessment -Kano State, ESSPIN. Retrieved on 20-10-2016. 
Special Conference Edition, November, 2017

Wootton, R. J. (1990). Ecology of Teleost Fishes, 1st Edition Chapman and Hall, London,

718pp. 